\title{
Primjena mrežne analize u psihologijskim istraživanjima
}

\author{
Anamarija Lonza
}

Sveučilište u Zagrebu, Filozofski fakultet, Odsjek za psihologiju, Zagreb, Hrvatska

\section{Sažetak}

Mrežni pristup predstavlja novu paradigmu u proučavanju odnosa između psiholoških konstrukata i manifestnih varijabli. Prema tome pristupu varijable tvore autonomni dinamički sustav, a konstrukt se ne promatra kao njihov uzrok, već kao rezultat njihove kompleksne međusobne interakcije. Analitički se taj pristup zasniva na metodi mrežne analize koja modelira varijable kao čvorove povezane skupom bridova. Ovaj rad predstavlja svojevrsni pregled skupa postupaka u mrežnoj analizi, odnosno nudi njihovo pojašnjenje te njihovu praktičnu primjenu na dvama različitim setovima podataka. Prvi set podataka predstavlja rezultate na upitniku DASS-21 $(N=1016)$ i u okviru njega demonstrirani su procjena parametara mreže, izračun mjera centralnosti čvorova, identifikacija klastera u mreži te provjera stabilnosti parametara. Rezultati pokazuju da najveću centralnost imaju čestica depresivnosti Osjetio/la sam kao da se nemam čemu radovati, čestica anksioznosti Osjetio/la sam da sam blizu panici i čestica stresa Osjećao/la sam se jako nervozno. Čvorovi mreže očekivano su se grupirali u tri klastera koji sadržajno reprezentiraju Depresivnost, Anksioznost i Stres. Analize stabilnosti pokazale su ograničenu stabilnost bridova, dok je stabilnost centralnosti čvorova ovisila o korištenoj mjeri. U drugome istraživanju, koje sadrži podatke o stavovima adolescenata prema izgledu vlastitoga tijela, prikazan je Test usporedbe mreža usporedbom mreže adolescenata $(n=524)$ i adolescentica $(n=763)$. Rezultati pokazuju da se dvije mreže komponenata stava o izgledu vlastitoga tijela ne razlikuju supstancijalno.

Ključne riječi: mrežni pristup, mrežna analiza, čvorovi, bridovi, mjere centralnosti

\section{Uvod}

Od samih je začetaka psihologije kao znanosti jedno od temeljnih pitanja koje se nameće u psihologijskim istraživanjima pitanje mjerenja, odnosno pitanje odnosa teorijskih psiholoških konstrukata, poput ekstraverzije, i opažljivih varijabli, kao što su, primjerice, pričljivost ili lako sklapanje prijateljstava. Trenutno postoje dva

Anamarija Lonza, Lovinčićeva 7, 10000 Zagreb, Hrvatska. E-pošta: anamarija. lonza@gmail.com

Zahvala

Hvala prof. dr. sc. Aleksandru Štulhoferu na nesebičnome ustupanju podataka iz vlastitoga istraživačkog projekta u svrhu demonstracije metoda mrežne analize. 
dominantna modela kojima se nastoji objasniti ta veza (Edwards i Bagozzi, 2000). Prema formativnome modelu opaženi indikatori „formiraju“ konstrukt, odnosno on se modelira kao funkcija tih indikatora. Pritom se pretpostavlja da različiti indikatori zahvaćaju različite aspekte konstrukta. Primjer je toga modela analiza glavnih komponenti (Schmittmann i sur., 2013). S druge strane, reflektivni model postulira da je teorijski konstrukt zajednički uzrok opaženim varijablama, odnosno one se modeliraju kao funkcija zajedničke latentne varijable i varijance pogreške. Za te modele vrijedi pretpostavka o lokalnoj neovisnosti, odnosno smatra se da su korelacije među opaženim indikatorima posljedica isključivo njihova zajedničkog uzroka. Primjer su toga modela konfirmatorna faktorska analiza (Edwards i Bagozzi, 2000) te različiti modeli teorije odgovora na zadatke (engl. Item Response Theory, IRT; Birnbaum, 1968; Rasch, 1960; Samejima, 1969; sve prema Schmittmann i sur., 2013).

U posljednjih se nekoliko godina u psihologiji kao nov konceptualni, ali i analitički pristup pojavljuje mrežni model (Borsboom, 2008; Borsboom i Cramer, 2013; Schmittmann i sur., 2013), ponajprije kako bi odgovorio na problem kompleksnosti fenomena koje psihologijska istraživanja proučavaju. Umjesto potrage za neopažljivim teorijskim konstruktom, gdje su opažene varijable tek pasivni indikatori latentne varijable, taj pristup predlaže izravno proučavanje veza među samim manifestnim varijablama koje predstavljaju autonomni dinamički sustav. Psihološki konstrukt stoga je radije konceptualiziran kao kompleksna mreža međusobno povezanih varijabli nego kao nadređeni entitet koji te varijable uzrokuje (Schmittmann i sur., 2013).

Mrežni pristup kao teorijska paradigma zasniva se na relativno novoj metodi mrežne analize (v. Costantini i sur., 2019; Epskamp, Borsboom i sur., 2018; Epskamp i sur., 2012; Epskamp i Fried, 2018). Riječ je o skupu postupaka koji omogućuju vizualizaciju kompleksnih odnosa među varijablama modelirajući ih kao čvorove (engl. node) koji su u mreži povezani bridovima (engl. edge). Na tako dobivenome grafičkom prikazu boja brida predstavlja smjer povezanosti (zelena boja upućuje na pozitivnu, a crvena na negativnu povezanost varijabli), dok debljina brida govori o snazi povezanosti (Epskamp i sur., 2012). Osim vizualizacije, moguće je odrediti i koje varijable zauzimaju centralnu, a koje više perifernu poziciju u mreži, kao i kako se varijable grupiraju u klastere. Konačno, razvijene su i metode za provjeru stabilnosti dobivene mrežne strukture (Epskamp, Borsboom i sur., 2018) te metode za usporedbu mreža različitih skupina sudionika (Van Borkulo i sur., 2016).

\section{Povijest razvoja}

Mrežni se pristup primarno razvio u području kliničke psihologije, no kasnije pronalazi svoju primjenu i u drugim područjima psihologije. U radu koji je postavio konceptualne temelje tome pristupu Borsboom (2008) argumentira da se dijagnostički pristup, koji se primjenjuje u području medicine da bi pojasnio zajedničku pojavu skupine simptoma, a koji je psihometrijski zasnovan na 
reflektivnome modelu, ne može adekvatno primijeniti na psihičke poremećaje. Za razliku od, primjerice, tumora, gdje su simptomi povezani isključivo zbog zajedničkoga uzroka u podlozi i gdje je ih moguće odvojiti od samoga poremećaja, psihički poremećaji nisu jasno odvojivi od svojih simptoma. Konkretno, osoba ne može dobiti dijagnozu depresije ako ne pokazuje simptome sniženoga raspoloženja i/ili gubitka interesa (Nuijten i sur., 2016). Također, upitno je u kojoj mjeri vrijedi pretpostavka o lokalnoj neovisnosti, odnosno koliko se povezanost dvaju simptoma može pripisati isključivo poremećaju u podlozi. Na primjer, gotovo je sigurno da depresija ne može u potpunosti objasniti korelaciju simptoma umora i nesanice (Cramer i sur., 2010). Mrežni pristup pojavio se, stoga, kao alternativa dominantnoj perspektivi zajedničkoga uzroka. Budući da predlaže proučavanje izravnih veza među simptomima umjesto njihova agregiranja u ukupni rezultat, otvara mogućnost određivanja centralnosti pojedinih simptoma u mreži određenoga poremećaja. Dosadašnja su istraživanja proučavala diferencijalnu centralnost simptoma depresivnoga poremećaja (Beard i sur., 2016; Boschloo i sur., 2016; Cramer i sur., 2010; Fried i sur., 2016), posttraumatskoga stresnog poremećaja (Armour i sur., 2017; Fried i sur., 2018; McNally i sur., 2015), generaliziranoga anksioznog poremećaja (Beard i sur., 2016; Cramer i sur., 2010), poremećaja hranjenja (Forbush i sur., 2016; Forrest i sur., 2018; Olatunji i sur., 2018; Rodgers i sur., 2018; Wang i sur., 2019), poremećaja ličnosti (Preszler i sur., 2018; Richetin i sur., 2017; Southward i Cheavens, 2018; Tsang i Salekin, 2019; Verschuere i sur., 2018) itd.

Osim toga, pristup nudi i novo gledište na komorbiditet, odnosno istodobnu pojavu više poremećaja. Umjesto proučavanja izravne povezanosti dviju kompozitnih mjera namijenjenih mjerenju dvaju poremećaja predlaže analizu veza među samim simptomima bez prethodne pretpostavke da su oni uzrokovani određenim psihičkim poremećajem. Premda su simptomi istoga poremećaja jače povezani, dok među simptomima različitih poremećaja ima manje veza i one su slabije, postoje određeni simptomi koji podjednako koreliraju sa simptomima i jednoga i drugog poremećaja (tzv. premosni simptomi), a koji bi u teoriji mogli objasniti pojavu komorbidnoga stanja (Cramer i sur., 2010). Neka su od dosadašnjih istraživanja proučavala, primjerice, komorbiditet depresije i različitih anksioznih poremećaja - generaliziranoga anksioznog poremećaja (Beard i sur., 2016; Cramer i sur., 2010), posttraumatskoga stresnog poremećaja (Afzali i sur., 2017) te opsesivnokompulzivnoga poremećaja (Jones i sur., 2018; McNally i sur., 2017).

Intuitivnost toga pristupa jako je brzo stekla popularnost i u drugim područjima osim kliničke psihologije. Ideja da psihološki konstrukt nastaje iz interakcije različitih afektivnih, kognitivnih i bihevioralnih komponenti primijenjena je u području psihologije ličnosti za objašnjenje osobina poput ekstraverzije ili savjesnosti (Cramer i sur., 2012). Dosadašnja su istraživanja proučavala mrežu čestica osobina petfaktorskoga modela (Cramer i sur., 2012) te modela HEXACO (Costantini, 2014). Pristup daje i novi smisao istraživanjima iz bihevioralne genetike. Točnije, pojašnjava moguće razloge pojavljivanja problema nedostajuće 
heritabilnosti (engl. missing heritability), odnosno nesklada između procjene umjereno visokoga indeksa heritabilnosti i nemogućnosti identifikacije odgovornih genetskih polimorfizama (Cramer i sur., 2012), kako za psihičke poremećaje, tako i za osobine ličnosti. Budući da se genetska istraživanja u najvećoj mjeri zasnivaju na reflektivnome modelu, ona nastoje povezati genetske polimorfizme sa sumom svih simptoma, odnosno sumom svih komponenata jedne dimenzije ličnosti. S druge strane, mrežna perspektiva predlaže da su same veze među čvorovima mreže pod genetskim utjecajem te da su različiti čvorovi i njihove povezanosti najvjerojatnije pod utjecajem različitih gena (Cramer i sur., 2011; Cramer i sur., 2012). Konačno, u području socijalne psihologije mrežni je pristup korišten za konceptualizaciju stavova kao uzročno povezanih evaluativnih reakcija (vjerovanja, osjećaja i ponašanja prema objektu stava; Dalege i sur., 2016). U proučavanju stavova gušće povezana mreža upućuje na veću otpornost stava na promjenu, kao i na veću vjerojatnost njegova iskazivanja u ponašanju (primjerice, pri donošenju odluka; Dalege i sur., 2019). Pritom su centralniji čvorovi one komponente koje imaju najveći utjecaj na ponašanje (Dalege, Borsboom, van Harreveld, Waldorp i sur., 2017) te predstavljaju najbolju metu za persuaziju (Dalege, Borsboom, van Harreveld i sur., 2017).

Cilj je ovoga rada prikazati osnovne postupke relativno nove metode mrežne analize na dvama nezavisnim skupovima podataka, pri čemu prvi potječe iz područja kliničke psihologije, a drugi iz područja socijalne psihologije. Premda će neke metode biti prikazane u prvome, a neke u drugome primjeru, svi opisani postupci mogu pronaći svoju primjenu u različitim područjima. Također je potrebno naglasiti da se ovaj rad bavi prikazom samo jednoga dijela mrežnih modela. Konkretno, riječ je o modelu koji se primjenjuje na podacima prikupljenima u jednoj vremenskoj točki i odmjerenima na ordinalnoj ili intervalnoj skali. O modelima koji koriste binarne varijable ili longitudinalni nacrt više se može pročitati drugdje (David i sur., 2018; Epskamp, Maris i sur., 2017; Epskamp, Waldorp i sur., 2018; Waldorp i sur., 2014). Sve su analize provedene $u$ programskome jeziku $R$ (verzija 3.5.2.) korištenjem paketa qgraph (Epskamp i sur., 2012), igraph (Csárdi i Nepusz, 2006), bootnet (Epskamp, 2019) i NetworkComparisonTest (Van Borkulo, 2019).

\section{Istraživanje 1.}

Na temelju podataka iz prvoga istraživanja bit će ilustrirani postupci procjene parametara mreže, izračuna mjera centralnosti, identifikacije klastera u mreži te na kraju i metode procjene stabilnosti dobivenih rezultata. 


\section{Metoda}

\section{Sudionici}

Podaci korišteni u ovome primjeru u prikupljeni su u svrhu izrade diplomskog rada autorice. Riječ je o rezultatima na upitniku DASS-21 (engl. Depression Anxiety Stress Scale; Lovibond i Lovibond, 1995) dobiveni na 1016 sudionika u dobnome rasponu između 22 i 84 godine $(M=31.03 ; S D=10.21)$, od čega je bilo $69.1 \%$ žena $(n=702)$. Zbog određenih ograničenja koja su bila postavljena za sudjelovanje u originalnome istraživanju sudionici većinom nisu bili studenti (63\%), a najveći je broj njih imao završen visok stupanj fakultetskoga obrazovanja (30.2 \% diplomski studij, $6.7 \%$ poslijediplomski studij). Prikupljanje podataka vršilo se pomoću onlineankete metodom snježne grude (lančanim prosljeđivanjem pojedinim osobama) te podjelom na društvenim mrežama (Facebook, Reddit), a trajalo je od ožujka do svibnja 2018. godine. Istraživanje je bilo dobrovoljno i anonimno te sudionici nisu dobili nikakvu naknadu za sudjelovanje.

\section{Mjerni instrumenti}

Kao mjera depresivnosti, anksioznosti i stresa korišten je upitnik DASS-21 (engl. Depression Anxiety Stress Scale; Antony i sur., 1998; Henry i Crawford, 2005; Lovibond i Lovibond, 1995). Riječ je o kratkoj skali u kojoj se od sudionika traži da procijene u kojoj su mjeri doživljavali simptome depresivnosti (npr. Osjetio/la sam kao da život nema smisla), anksioznosti (npr. Bio/la sam uplašen/a bez opravdanoga razloga) i stresa (npr. Bilo mi je teško opustiti se) u posljednjih tjedan dana na skali od četiri stupnja (0 - Uopće se nije odnosilo na mene, 3 - Gotovo u potpunosti ili većinu vremena se odnosilo na mene). Ukupni rezultat formiran je kao jednostavna linearna kombinacija svih čestica upitnika, pri čemu viši rezultat ukazuje na veću izraženost simptoma. Upitnik se sastoji od 21 čestice te se teorijski raspon odgovora kretao od 0 do 63, dok je vrijednost Cronbachova alfa koeficijenta, kao i u prijašnjemu istraživanju (Henry i Crawford, 2005), iznosila .93.

\section{Procjena parametara}

Kako bismo provjerili mrežnu strukturu simptoma koje mjeri upitnik DASS-21, izrađena je mreža s česticama upitnika kao čvorovima, dok su bridove predstavljale njihove parcijalne korelacije. Mreže parcijalnih korelacija, poznate i pod nazivom Gaussian graphical models (GGMs), pripadaju široj skupini statističkih modela zvanih Markovljeva slučajna polja (engl. pairwise Markov random fields; PMRF) koji se zasnivaju na uvjetnoj nezavisnosti. Naime, prisutnost brida u tako dobivenoj mreži označava da dva čvora nisu nezavisna kada se kontrolira njihova povezanost $\mathrm{s}$ preostalim čvorovima u mreži (Epskamp i Fried, 2018). Točnije, mreža zapravo predstavlja multipli linearni regresijski model u kojemu se svaki od čvorova predviđa 
na temelju svih preostalih čvorova (Fried i Cramer, 2017). Premda čvorovi u mreži mogu predstavljati i skalne rezultate ili faktore, često se, kao i u ovome slučaju, kao čvorovi koriste same čestice upitnika. Stoga su kao ulazne varijable za analizu uobičajeno korištene polihoričke korelacije - one služe za procjenu povezanosti varijabli za koje se pretpostavlja da su inače kontinuirane i normalno distribuirane, ali su odmjerene na ordinalnoj skali (Beard i sur., 2016). Usto, korištenje samih čestica kao čvorova često vodi problematičnomu omjeru veličine uzorka i broja parametara koje je potrebno procijeniti. Parametri koji se procjenjuju u mreži međusobne su korelacije $n$ čvorova $(n(n-1) / 2)$ te njihove autokorelacije $(n)$, odnosno 21 čvor zahtijeva procjenu 231 parametra, a Fried i Cramer (2017) nalažu da minimalni omjer podrazumijeva barem tri sudionika po parametru. Budući da je u psihologijskim istraživanjima veličina uzorka često ograničena, preporuka je prilikom provedbe mrežne analize smanjiti broj procjenjivanih parametara korištenjem nekoga oblika regularizacije. Česta je upotreba metode regularizacije graphical LASSO (engl. Least Absolute Shrinkage and Selection Operator) koja ograničava sumu apsolutnih vrijednosti parametara te posljedično marginalne parametre svodi na nulu i isključuje ih iz modela (više o implementaciji v. u Epskamp i Fried, 2018). Korištenje regularizacije minimalizira pojavu lažno pozitivnih bridova te tipično rezultira boljom stabilnošću i interpretabilnijom mrežnom strukturom (Epskamp, Kruis i sur., 2017).

\section{Mjere centralnosti}

Jedna je od prednosti mrežne analize kao analitičkoga postupka mogućnost određivanja centralnosti pojedinih čvorova u mreži. Nekoliko je najčešće korištenih mjera centralnosti, a one se temelje na najkraćoj dužini puta (engl. shortest path length, SPL), odnosno minimalnome broju bridova koji je potrebno prijeći da bi se došlo od jednoga do drugog čvora (Borsboom i Cramer, 2013). SPL je u ponderiranoj mreži baziran na Dijkstrinom algoritmu koji minimalizira recipročnu vrijednost udaljenosti između dvaju čvorova, pri čemu se pri izračunu udaljenosti u obzir mogu uzeti i broj bridova koje čvorovi dijele i ponderi tih bridova (Opsahl i sur., 2010). Prva se mjera centralnosti naziva stupanj čvora (engl. node degree) i ona predstavlja broj čvorova s kojima je neki čvor izravno povezan. U ponderiranim se mrežama ta mjera naziva snaga čvora (engl. node strength) i u osnovi predstavlja sumu apsolutnih vrijednosti pondera izravnih veza (Opsahl i sur., 2010). Slična je prethodnoj mjera očekivanoga utjecaja (engl. node expected influence) koja sumira vrijednosti pondera koje neki čvor izravno dijeli s ostalima, no za razliku od snage, u obzir uzima i predznak njihovih vrijednosti te se njezino korištenje preporučuje kada mreža sadrži i negativne korelacije (Robinaugh i sur., 2016). Nadalje, centralnost blizine (engl. closeness centrality) predstavlja recipročnu vrijednost sume svih najkraćih dužina puta između nekoga čvora i svih ostalih čvorova u mreži, odnosno ona odgovara na pitanje koliko brzo taj čvor može „doći“ do ostalih. Konačno, centralnost međusobnosti (engl. betweenness centrality) govori nam 
koliko puta neki čvor leži na najkraćemu putu između drugih dvaju čvorova, odnosno ona predstavlja potencijalnu premosnicu između tih čvorova (Opsahl i sur., 2010).

\section{Identifikacija klastera}

Osim centralnosti pojedinih čvorova, može nas zanimati i na koji se način ti čvorovi grupiraju u mreži. U tu se svrhu uobičajeno koristi tzv. algoritam spinglass koji pronalazi klastere tako da broj i ponderirana snaga bridova unutar klastera budu veći od broja i snage bridova među čvorovima različitih klastera (Heeren i McNally, 2016). Budući da je taj algoritam po prirodi nedeterministički, odnosno rezultati se mogu razlikovati u više iteracija (Werner, 2018), u ovome je radu izabrano najstabilnije rješenje dobiveno u 1000 različitih iteracija.

\section{Stabilnost mreže}

Konačno, budući da mrežna analiza, kako je već rečeno, zahtijeva procjenu jako velikoga broja parametara, vrlo je važno ispitati koliko su dobiveni rezultati stabilni, odnosno koliko je vjerojatno da bi se replicirali na novome uzorku. Epskamp i suradnici (2018) predložili su metode za procjenu stabilnosti samih bridova, kao i mjera centralnosti. Kad je riječ o snazi bridova, metodom bootstrap ponavljano se procjenjuje mreža na temelju uzorkovanih ili simuliranih podataka te je moguće dobiti intervale pouzdanosti oko bridova. Na temelju rezultata možemo primijetiti koliko su dobiveni intervali šroki, kao i postoje li preklapanja intervala različitih bridova. Međutim, bitno je napomenuti da u slučaju korištenja regularizacije taj test ne bi smio služiti ispitivanju razlikuje li se brid značajno od nule jer sama činjenica da brid prilikom regularizacije nije sveden na nulu upućuje na to da je on dovoljno jak da bude uključen u model. S druge strane, za ispitivanje stabilnosti određene mjere centralnosti provodi se test koji provjerava ostaje li poredak mjere centralnosti čvorova isti kad se mreža procjenjuje sa sve manjim i manjim $N$-om (engl. $m$ out of $n$ bootstrap). Konačni je rezultat toga testa tzv. koeficijent stabilnosti korelacije (engl. correlation stability coefficient) koji predstavlja maksimalnu proporciju ispitanika koja se može isključiti, a da s 95 \% sigurnosti možemo reći da je korelacija originalnih mjera centralnosti i onih dobivenih na manjemu uzorku .70 ili viša. Preporučuje se da taj koeficijent ne bude ispod .25 , a poželjno bi bilo da je iznad .50 (Epskamp i sur., 2018).

\section{Rezultati i rasprava}

Slika 1. prikazuje procijenjenu mrežu čestica upitnika DASS-21 u kojoj su pozitivne korelacije prikazane punom crtom, a negativne isprekidanom, dok su jače veze označene debljim i tamnijim bridovima (vrijednosti veličina bridova vidljive su u Tablici 1.). Mreža je vizualizirana Fruchterman-Reingoldovim algoritmom koji smješta jače povezane čvorove bliže jedan drugomu (Fruchterman i Reingold, 1991). 


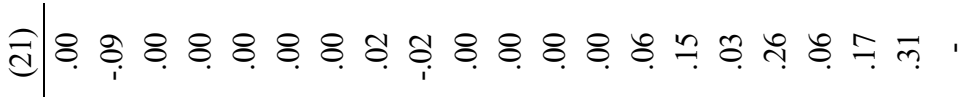

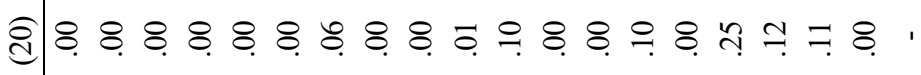

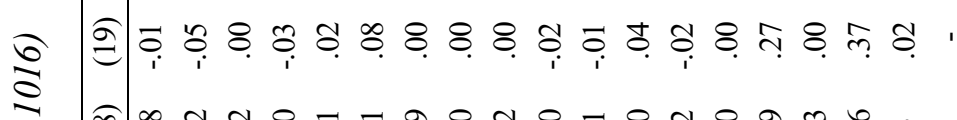

II $\triangleq$ \&

: ะิ

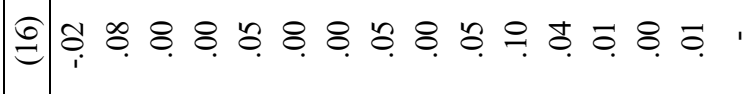

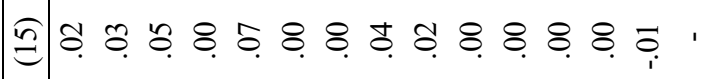

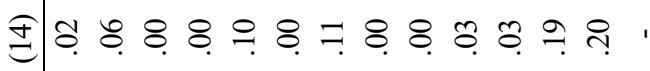

กิ

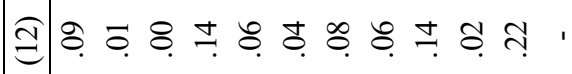

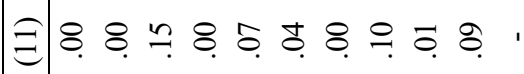

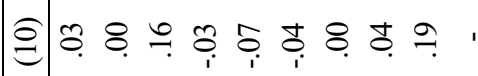

๘ิ 8.8.

के \&. :

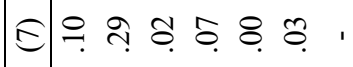

$68 \% 8 \%$

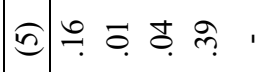

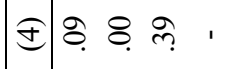

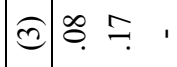

ฮิ $\vec{\Upsilon}$

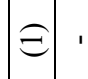

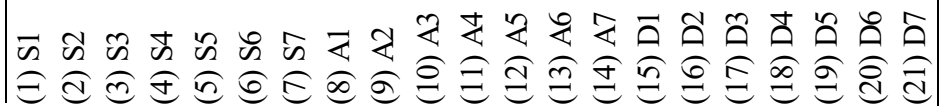


Slika 1.

Mrežna struktura čestica Skale depresivnosti, anksioznosti i stresa $(N=1016)$

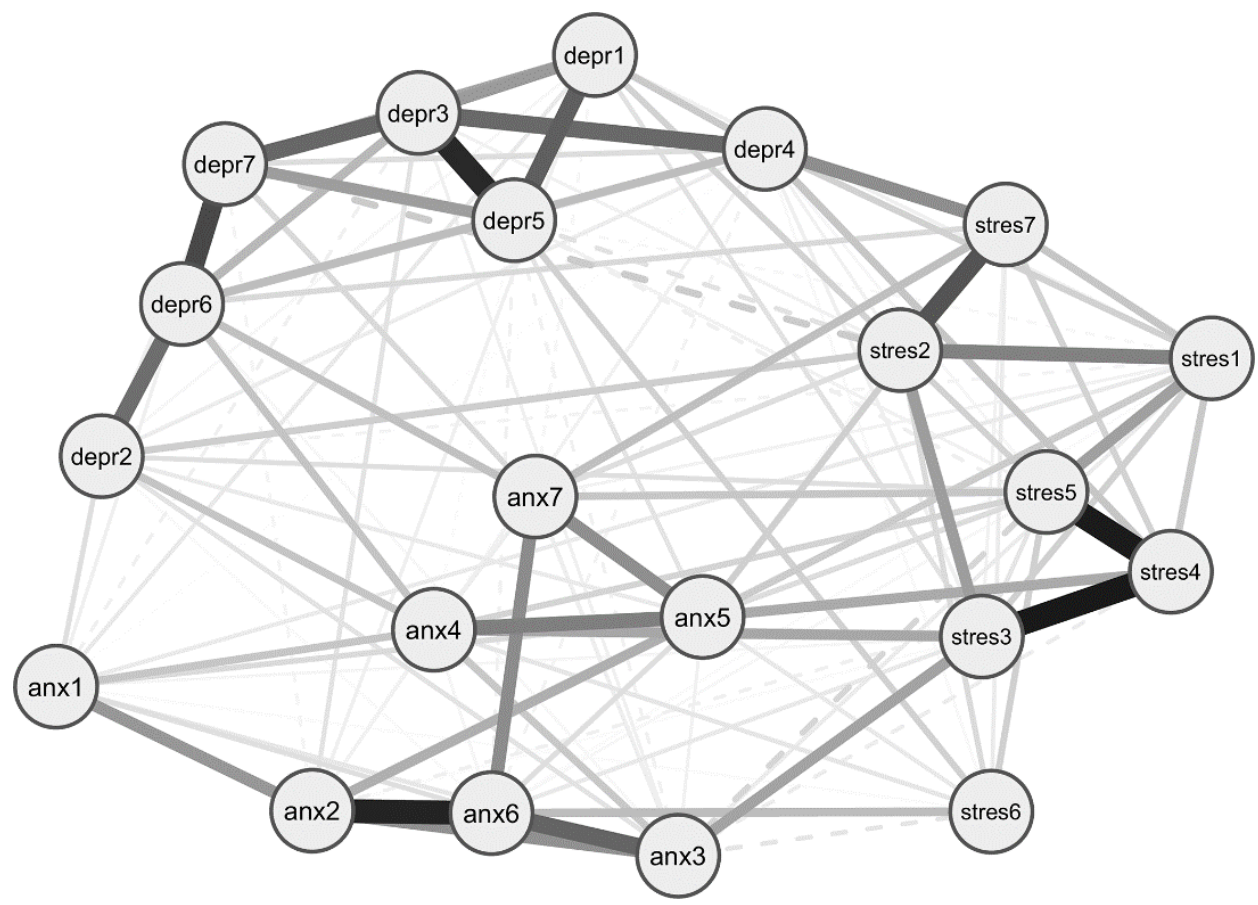

Napomene:

Depr1: Uopće nisam mogao/la doživjeti neki pozitivan osjećaj.

Depr2: Bilo mi je teško započeti aktivnosti.

Depr3: Osjetio/la sam kao da se nemam čemu radovati.

Depr4: Bio/la sam potišten/a i tužan/na.

Depr5: Ništa me nije moglo oduševiti.

Depr6: Osjetio/la sam da ne vrijedim mnogo kao osoba.

Depr7: Osjetio/la sam kao da život nema smisla. Anx1: Sušila su mi se usta.

Anx2: Doživio/la sam teškoće s disanjem (npr. ubrzano disanje, gubitak daha bez fizičkoga napora).

Anx3: Doživljavao/la sam drhtanje (npr. u rukama).

Anx4: Zabrinjavale su me situacije u kojima bih mogao/la paničariti ili se osramotiti.
Anx5: Osjetio/la sam da sam blizu panici.

Anx6: Bio/la sam svjestan/na rada svoga srca bez fizičkoga napora (npr. osjećaj preskakanja i ubrzanoga rada srca).

Anx7: Bio/la sam uplašen/a bez opravdanoga razloga.

Stres1: Bilo mi je teško smiriti se.

Stres2: Bio/la sam sklon/a pretjeranim reakcijama na događaje.

Stres3: Osjećao/la sam se jako nervozno.

Stres4: Osjetio/la sam da postajem uznemiren/a.

Stres5: Bilo mi je teško opustiti se.

Stres6: Nisam podnosio/la da me išta ometa $u$ onome što sam radio/la.

Stres7: Događalo mi se da sam bio/la prilično osjetljiv/a.

Na Slici 2. prikazan je graf s mjerama centralnosti čvorova. Budući da je, kako će kasnije biti demonstrirano, očekivani utjecaj najstabilnija od mjera centralnosti te 
se preporučuje njezino korištenje kada mreža sadrži negativne bridove, najviše smisla ima promatrati njezine veličine prilikom interpretacije centralnosti čvorova.

Slika 2.

Mjere centralnosti čestica Skale depresivnosti, anksioznosti i stresa $(N=1016)$
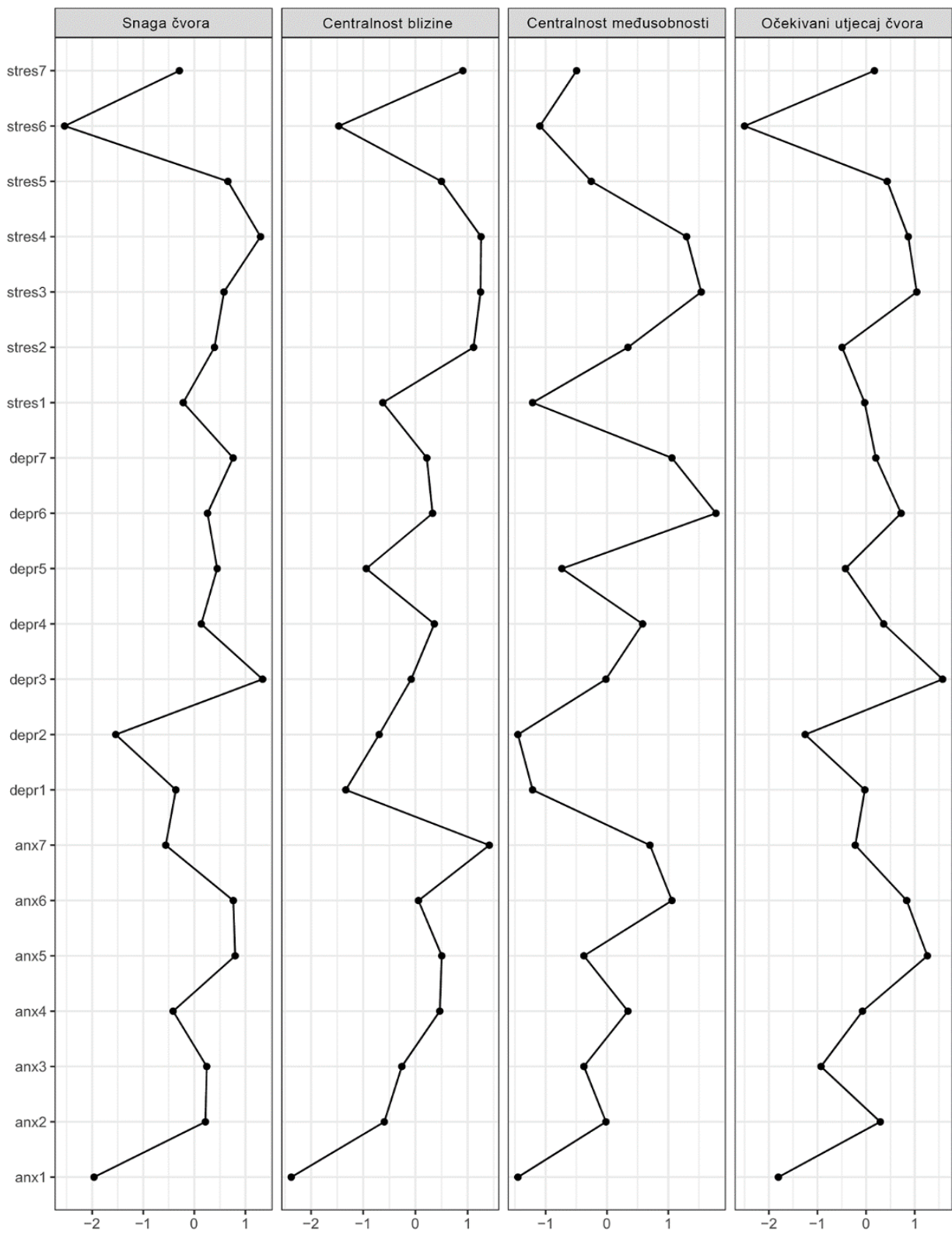
Iz grafa je vidljivo da najveći očekivani utjecaj imaju treća čestica depresivnosti (Osjetio/la sam kao da se nemam čemu radovati), peta čestica anksioznosti (Osjetio/la sam da sam blizu panici) i treća čestica stresa (Osjećao/la sam se jako nervozno), dok su najmanje centralne prva čestica anksioznosti (Sušila su mi se usta) i šesta čestica stresa (Nisam podnosio/la da me išta ometa u onome što sam radio/la). Čvorovi koji u mreži zauzimaju središnji položaj predstavljaju potencijalno važne točke za planiranje intervencija - budući da je riječ o simptomima koji su najsnažnije povezani $\mathrm{s}$ preostalim simptomima, pretpostavka je da će upravo razrješenje tih simptoma „,deaktivirati“" mrežu i vratiti pojedinca u stanje psihičkoga zdravlja (Beard i sur., 2016).

Prilikom primjene algoritma spinglass najstabilnijim se pokazalo rješenje na Slici 3. Ono ukazuje na postojanje triju različitih klastera ${ }^{1}$ koji sadržajno odgovaraju trima komponentama koje bi upitnik trebao mjeriti. Takvo rješenje predstavlja svojevrsni dokaz u prilog valjanosti samoga upitnika, odnosno upućuje na to da je riječ o trima međusobno distinktivnim konstruktima.

Slika 3.

Klasteri čestica upitnika DASS-21 dobiveni na temelju algoritma spinglass $(N=1016)$

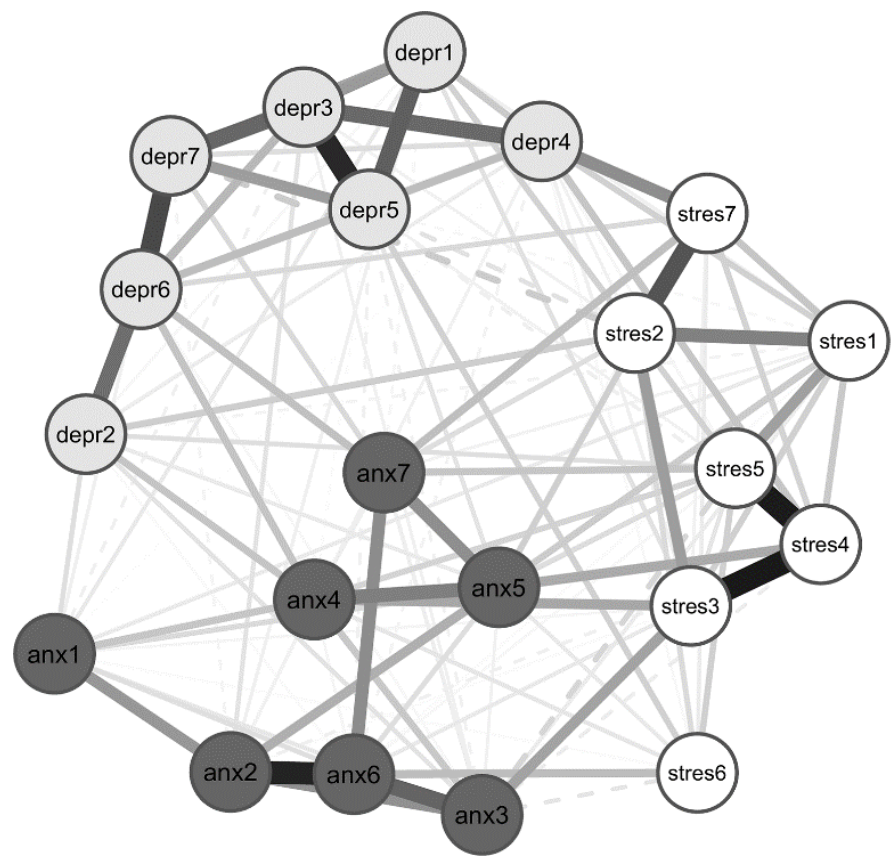

Konačno, provedene su analize stabilnosti dobivenih rezultata te je na Slici 4. prikazana stabilnost bridova, dok je na Slici 5. vidljiva stabilnost mjera centralnosti.

\footnotetext{
${ }^{1}$ Kako bi se omogućila provjera centralnosti s obzirom na klastere simptoma, razvijene su i mjere premosne centralnosti (engl. bridge centrality; za detalje v. Jones i sur., 2019), odnosno na temelju njih moguće je izračunati koji je čvor iz jednoga klastera najbolje povezan $\mathrm{s}$ čvorovima drugoga klastera.
} 
U prikazu stabilnosti bridova radi preglednosti izostavljeni su nazivi bridova. Premda se veličina uzorka čini dovoljno velikom $(N=1016)$, odnosno omjer broja parametara i broja sudionika iznosi $1: 4$, na temelju rezultata metode bootstrap vidljivo je da su dobiveni intervali prilično široki te pokazuju izrazita preklapanja, što ukazuje na ograničenu stabilnost bridova. S druge strane, rezultati stabilnosti mjera centralnosti pokazuju zadovoljavajuću stabilnost očekivanoga utjecaja i snage čvora, čiji koeficijenti stabilnosti korelacije iznose .75 i .59 , dok su preostale dvije mjere centralnosti (centralnost blizine i centralnost međusobnosti) manje stabilne (CSkoeficijenti veličine 21 i .05). Slabija stabilnost posljednjih dviju mjera nalaz je koji se dobiva i u drugim istraživanjima (Beard i sur., 2016; Epskamp, Borsboom i sur., 2018; Santos i sur., 2018) pa se preporučuje oprez u njihovu interpretiranju.

Slika 4.

Bootstrap-intervali pouzdanosti procijenjenih bridova u mreži čestica upitnika DASS-21

- Bootstrap $M \quad$-Uzorak

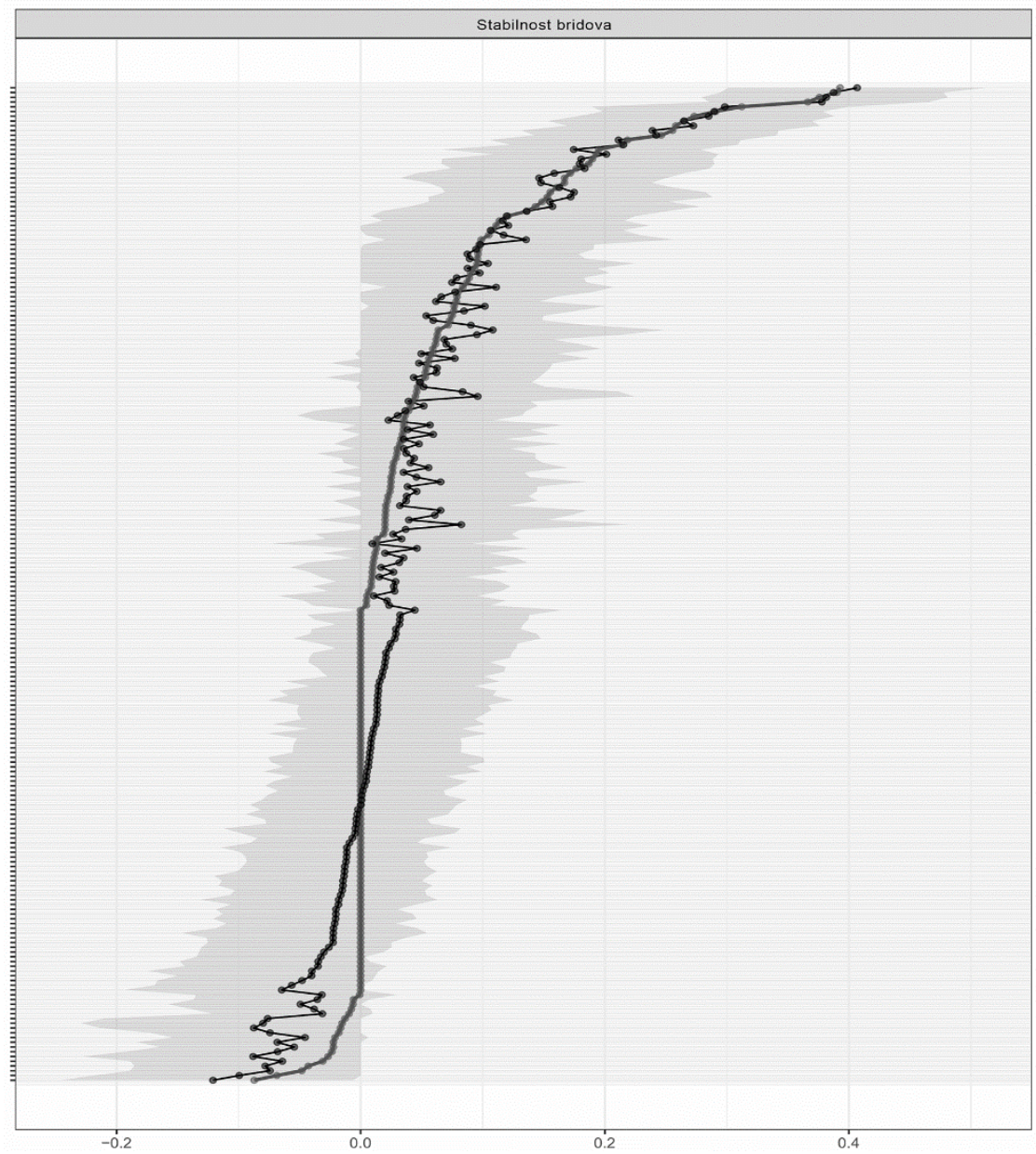


Lonza, A.:

Primjena mrežne analize u psihologiji

Slika 5.

Rezultati analize stabilnosti mjera centralnosti za mrežu čestica DASS-21

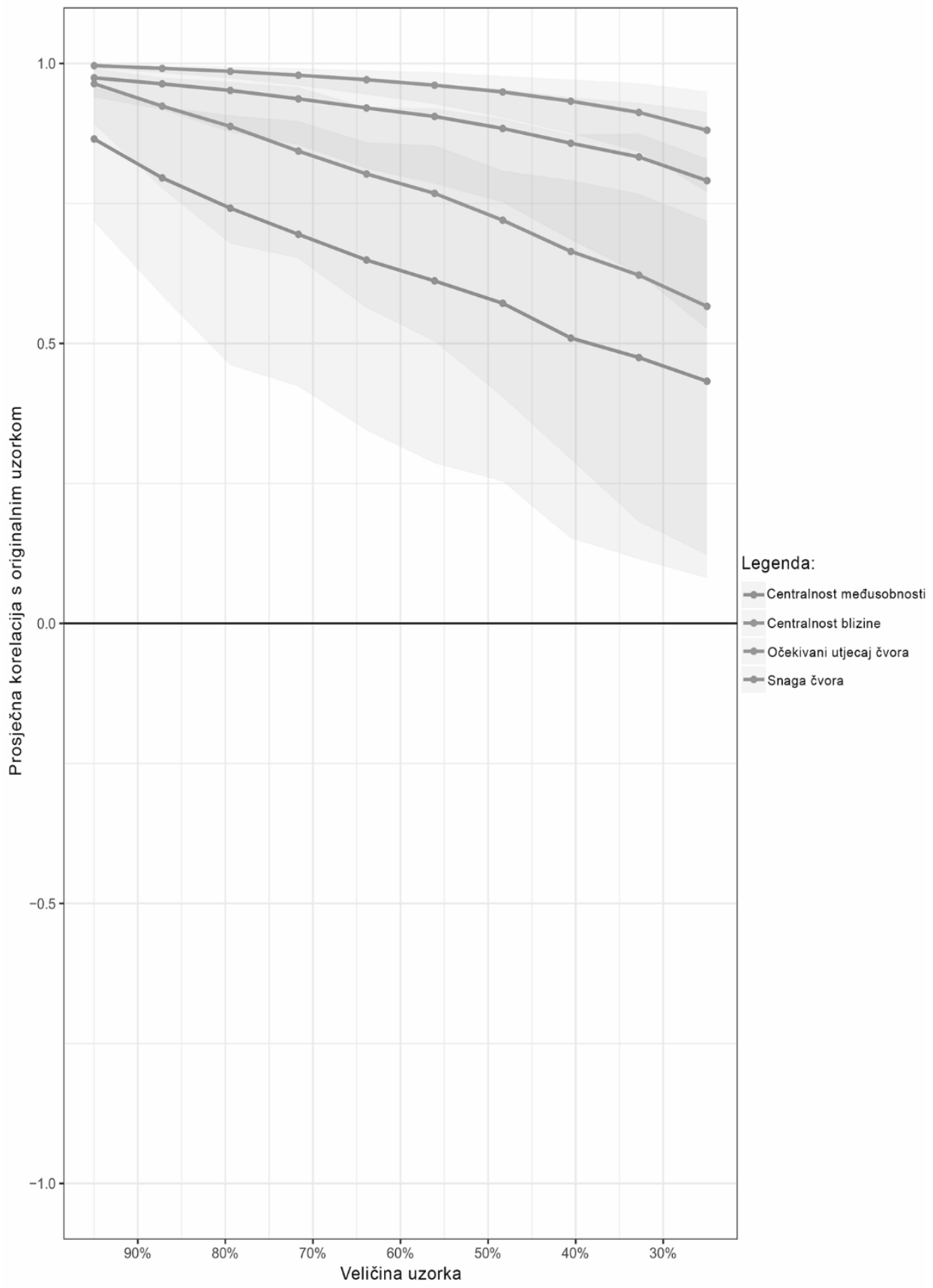


Dobiveni rezultati provedeni su na zajedničkome uzorku muškaraca i žena, premda je moguće da bi se izradom dviju odvojenih mreža ovisno o rodu uočile određene razlike u centralnosti simptoma s obzirom na rod. Sljedeći će primjer stoga ilustrirati još jedan statistički test koji može biti koristan prilikom analize podataka, a koji se odnosi na usporedbu mreža dviju različitih skupina sudionika.

\section{Istraživanje 2.}

Za razliku od prethodnoga skupa podataka koji potječe iz područja kliničke psihologije, ovaj će primjer prikazati skup podataka iz istraživanja u socijalnoj psihologiji. Riječ je o širemu istraživačkom projektu koji se bavio biopsihosocijalnim utjecajima seksualno eksplicitnih materijala na seksualnu socijalizaciju i zdravlje hrvatskih adolescenata (Milas i sur., 2020). Između ostaloga, u okviru projekta prikupljeni su i podaci o stavovima adolescenata prema izgledu vlastitoga tijela, gdje su se promatrale tri komponente - odnos adolescenata prema vlastitome tijelu, usvojenost društvenoga ideala o tjelesnome izgledu te samonadzor, odnosno okupiranost vlastitim izgledom (Ciprić i Landripet, 2017). Cilj analiza koje slijede bio je provjeriti mrežnu strukturu čestica koje mjere te tri komponente odvojeno na muškome i ženskom poduzorku te ispitati postoje li značajne razlike između tih dviju mreža.

\section{Metoda}

\section{Sudionici}

Istraživanje je provedeno na panel-uzorku adolescenata, učenika drugoga razreda ukupno 14 riječkih srednjih škola, u šest vremenskih točaka. Podaci prikazani u sljedećim analizama prikupljeni su u prvome valu istraživanja, u prosincu 2015. godine, na 1287 sudionika (od čega $59.3 \%$ žena, $n=763$ ), dobi između 15 i 18 godina $(M=15.9, S D=0.52)$.

\section{Mjerni instrumenti}

Skala zadovoljstva tjelesnim izgledom. Kako bi se ispitao odnos adolescenata prema vlastitome tijelu, korištena je skraćena verzija subskale izgleda koja je dio višedimenzionalne mjere zadovoljstva tjelesnim izgledom za adolescente i odrasle (Body Esteem Scale for Adolescents and Adult-Appearance subscale; Mendelson i sur., 2001). Slaganje s četirima česticama (Izgledam baš kao što bih želio/la, Sviđa mi se što vidim kada se pogledam u ogledalu, Postoje mnoge stvari koje bih promijenio/la u svome izgledu da mogu, Ponosan/na sam na svoje tijelo) sudionici su procjenjivali na skali od pet stupnjeva (1 - Uopće se ne slažem, 5 -U potpunosti se slažem). Viši rezultat upućivao je na veće zadovoljstvo izgledom, no skala je 
pokazala nezadovoljavajuću pouzdanost tipa unutarnje konzistencije (Cronbachov alfa koeficijent iznosio je .37).

Skala sociokulturnih stavova prema izgledu. Skraćena verzija subskale internalizacije iz višedimenzionalne Skale sociokulturnih stavova prema izgledu (Sociocultural Attitudes Toward Appearance Scale - Internalization Subscale; Thompson i sur., 2004) korištena je kako bi se izmjerila usvojenost društvenoga ideala o tjelesnome izgledu. Subskala se sastoji od četiriju čestica (Želio/la bih da moje tijelo izgleda poput tijela filmskih glumacalica $i$ modela iz časopisa, Uspoređujem svoj izgleds izgledom popularnih osoba (celebrities), Želio/la bih izgledati poput pjevača/ica i plesača/ica u glazbenim spotovima, Želio/la bih da moje tijelo izgleda kao tijelo vrhunskoga sportaša/ice), a odgovor se davao na ljestvici od 5 stupnjeva (1 - Uopće se ne slažem, 5 - U potpunosti se slažem). Veći je rezultat odražavao viši stupanj internalizacije društvenih ideala tjelesnoga izgleda, a Cronbachov alfa koeficijent iznosio je .76, što upućuje na prihvatljivu pouzdanost.

Skala objektiviziranja tijela. Subskalom samonadzora iz višedimenzionalne Mjere objektiviziranja tijela za adolescente (Objectified Body Consciousness Scale for Adolescents - Body Surveillance subscale; Lindberg i sur., 2006) nastojalo se izmjeriti opterećenost adolescenata svojim izgledom uz pomoć četiriju čestica na kojima su trebali procijeniti koliko često: (i) uspoređuju svoj izgled s izgledom drugih; (ii) razmišljaju kako izgledaju tijekom dana; (iii) brinu izgledaju li dobro u svojoj odjeći; i (iv) brinu kako izgledaju drugim ljudima. Pritom se odgovor davao na skali od četiri stupnja $(1-N i k a d, 4-$ Cesto), a veći je rezultat odražavao veću opterećenost izgledom. Mjera se pokazala prihvatljivo pouzdanom (Cronbachov alfa koeficijent iznosio je .78).

\section{Usporedba mreža}

Kako bismo usporedili mrežnu strukturu triju komponenata stavova prema izgledu vlastitoga tijela između adolescenata i adolescentica, korišten je Test usporedbe mreža (engl. Network Comparison Test, NCT; Van Borkulo, 2019). Tim se testom ispituju tri mjere invarijantnosti mreže između dviju grupa - (a) invarijantna mrežna struktura, (b) invarijantna snaga bridova i (c) invarijantna globalna snaga mreže (Santos i sur., 2018). Kako bi se utvrdilo je li mrežna struktura invarijantna, prvo se procjenjuje mrežna struktura dviju grupa na opaženim podacima te se računa statistička vrijednost $M$ koja predstavlja najveću razliku apsolutnih veličina ekvivalentnih bridova između dviju mreža. U drugome se koraku toga postupka grupna pripadnost ponavljano i nasumično dodjeljuje pojedinim ispitanicima $i$ ista statistička vrijednost računa se na tako dobivenim permutacijama, što rezultira distribucijom koja omogućuje testiranje statističke značajnosti opaženoga testa (Van Borkulo i sur., 2016). Ako se taj test pokaže statistički značajnim, mogu se izračunati i post-hoc testovi korištenjem Holm-Bonferronijeve korekcije za višestruka testiranja, kako bi se istražili specifični bridovi koji se 
razlikuju u dvjema mrežama (Fried i sur., 2018). Konačno, test invarijantnosti globalne snage mreže testira imaju li mreže, premda se možda i razlikuju u strukturi, jednaku snagu, odnosno podjednaku sumu apsolutnih vrijednosti svih bridova (Van Borkulo i sur., 2016).

\section{Rezultati i rasprava}

Budući da su čestice odmjerene na različitim ljestvicama te su se stoga razlikovale u varijabilitetu, one su prije procjene mreže standardizirane. Na Slici 6. vizualizirane su mreže stavova o izgledu vlastitoga tijela za adolescente i adolescentice. Pri vizualizaciji svake od njih prvotno je korišten FruchtermanReingoldov algoritam, no u konačnome je prikazu primijenjen uprosječeni raspored čvorova prve i druge mreže kako bi se olakšala njihova usporedba.

Rezultati Testa usporedbe mreža pokazuju da se mreže adolescenata $\mathrm{i}$ adolescentica ne razlikuju prema ukupnoj snazi bridova $(S=0.07 ; p=.78)$, no postoji statistički značajna razlika u njihovoj strukturi $(M=0.17 ; p=.04)$, što znači da bridovi tih dviju mreža nisu posve jednaki. Ipak, budući da taj test, uz dovoljno statističke snage, može ukazati na statistički značajno razlikovanje mreža čak i ako se one razlikuju samo u jednome bridu (Fried i sur., 2018), provedeno je i post-hoc testiranje za usporedbu pojedinačnih bridova. Ono je pokazalo da se te dvije mreže uistinu značajno razlikuju samo u jednome bridu, i to onome između prve (Želio/la bih da moje tijelo izgleda poput tijela filmskih glumaca/ica i modela iz časopisa) i četvrte čestice subskale internalizacije (Želio/la bih da moje tijelo izgleda kao tijelo vrhunskoga sportaša/ice), u smjeru veće povezanosti tih dviju čestica u mreži adolescenata. Konačno, klasterizacija mreže pomoću algoritma spinglass ukazala je na grupiranje čestica $u$ istim trima klasterima u objema mrežama - riječ je o klasterima koji sadržajno odgovaraju trima komponentama (izgled, internalizacija, nadzor), s iznimkom treće čestice subskale izgleda (Postoje mnoge stvari koje bih promijenio/la u svome izgledu da mogu) koja se u objema mrežama pripojila klasteru čestica nadzora (uzmemo li u obzir nisku pouzdanost subskale izgleda, taj nalaz nije iznenađujući). Iz svega navedenoga možemo zaključiti da su dvije mreže uvelike slične te da struktura komponenata stava o izgledu vlastitoga tijela ne pokazuje supstancijalne razlike s obzirom na rod.

\section{Ograničenja}

Konačno, potrebno je istaknuti i određena ograničenja mrežne analize kao metode. Mrežna analiza može se usporediti s nizom povezanih multiplih regresijskih modela gdje se svaki čvor predviđa na temelju svih preostalih čvorova. Stoga ona može poslužiti otkrivanju potencijalnih medijacijskih efekata identifikacijom čvorova koji su povezani indirektno putem zajedničkoga čvora (Epskamp i Fried, 2018). Međutim, prilikom procjene samih bridova mreže dolazi do problema pojave lažno pozitivnih bridova. Kao alternativa testiranju statističke značajnosti bridova, 
Slika 6.

Mrežna struktura komponenti stavova prema vlastitome tijelu na muškome $(n=524) i$ ženskom poduzorku $(n=763)$
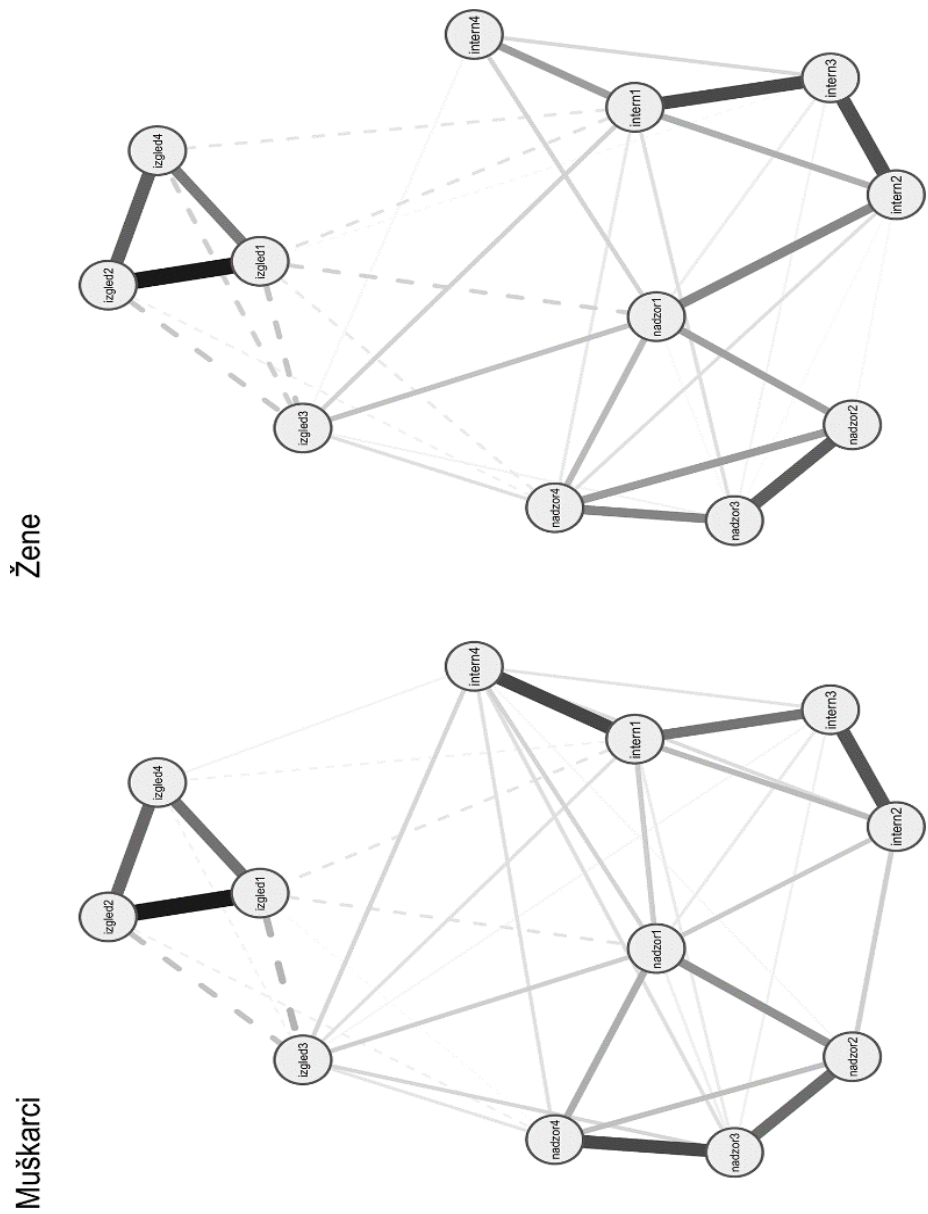

\section{Legenda:}

Izgled1: Izgledam baš kao što bih želio/la.

Izgled2: Sviđa mi se što vidim kada se pogledam u ogledalu.

Izgled3: Postoje mnoge stvari koje bih promijenio/la u svome izgledu da mogu.

Izgled4: Ponosan/na sam na svoje tijelo.

Intern1: Želio/la bih da moje tijelo izgleda poput tijela filmskih glumaca/ica i modela iz časopisa.

Intern2: Uspoređujem svoj izgled s izgledom popularnih osoba (celebrities).
Intern3: Želio/la bih izgledati poput pjevača/ica i plesača/ica u glazbenim spotovima.

Intern4: Želio/la bih da moje tijelo izgleda kao tijelo vrhunskoga sportaša/ice.

Nadzor1: Često uspoređujem svoj izgled s izgledom drugih.

Nadzor2: Često razmišljam kako izgledam tijekom dana.

Nadzor3: Često brinem izgledam li dobro u svojoj odjeći.

Nadzor4: Često brinem kako izgledam drugim ljudima. 
koje uvodi problem višestrukoga testiranja (odnosno pada statističke snage u slučaju korištenja korekcija; Epskamp i Fried, 2018), česta je uporaba regularizacije LASSO. Epskamp, Kruis i sur. (2017) upozoravaju na to da ona počiva na pretpostavci da je stvarna struktura mreže prorijeđena pa procjena parametara korištenjem regularizacije posljedično može rezultirati lažno negativnim bridovima, odnosno isključiti iz mreže bridove koji zapravo postoje. Stoga je potrebna određena doza opreza prilikom donošenja zaključaka na temelju tako procijenjenih mreža.

Nadalje, za razliku od analize socijalnih mreža (engl. social network analysis), gdje bridovi predstavljaju veze između entiteta koje su unaprijed poznate i opažljive (Epskamp i Fried, 2018), ovdje je riječ o parametrima modela koje je potrebno procijeniti. Postojeće su mjere centralnosti ponajprije razvijene za socijalne mreže i ondje je njihova upotreba puno jasnija i jednoznačnija - primjerice, u mreži poznanstava čvor koji ima najveći stupanj bit će osoba koja poznaje najviše ljudi. U slučaju analize psiholoških mreža sve se više postavlja pitanje značenja i prikladnosti korištenja tih mjera (vidi Bringmann, 2016; Bringmann i sur., 2019; Epskamp, 2017). Primjerice, nije posve jasno mogu li bridovi u psihološkim mrežama reprezentirati protok informacija kroz mrežu. Također, za razliku od socijalnih mreža, gdje su čvorovi potpuno nepreklapajući entiteti, kada kao čvorove u psihološkim mrežama koristimo čestice upitnika, nerijetko nailazimo na problem njihove multikolinearnosti, što dovodi u pitanje značenje njihove centralnosti. Konačno, mjere centralnosti blizine i centralnosti međusobnosti, kako je demonstrirano i u ovome radu, karakterizira izrazito slaba stabilnost, stoga se preporučuje izbjegavanje njihova korištenja (Bringmann i sur., 2019).

Kada je riječ o stabilnosti dobivene mreže, zadovoljavajući pokazatelji stabilnosti upućuju na veću vjerojatnost repliciranja rezultata na drugim, sličnim uzorcima. Međutim, ne treba zaboraviti da nam takve analize ne govore ništa o pitanju repliciranja dobivene mrežne strukture na uzorcima značajno različitima od našega, primjerice, $u$ drugim kulturama.

Zaključno, mrežni su modeli nastali kao alternativa modelima latentnih varijabli, s ciljem pružanja nove perspektive. Ipak, kako navodi Molenaar (2010), mrežni su modeli u nekim slučajevima statistički ekvivalentni modelima latentnih varijabli te stoga možda i ne uvode toliko veliku novost koliko se predstavlja.

\section{Zaključak}

Mrežni je pristup relativno nova paradigma i tek pronalazi svoju primjenu u različitim područjima psihologije. Svrha je ovoga rada bila pružiti pregled osnovnih metoda mrežne analize i njihove primjene na različitim podacima, kako bi se uvidio njezin potencijalni značaj za buduća psihologijska istraživanja. U Istraživanju 1. pružili smo uvid u procjenu parametara mreže, mjere centralnosti, identifikaciju klastera te parametre stabilnosti rezultata na stvarnim podacima iz područja kliničke 
psihologije. S druge strane, u Istraživanju 2. detaljnije je pojašnjen test za usporedbu mreža dviju skupina na podacima iz područja socijalne psihologije. Iako se metodologija mrežne analize intenzivno razvija i nadograđuje, nadamo se da će ovaj rad poslužiti za uvodno snalaženje i bolje razumijevanje radova koji koriste tu metodologiju.

\section{Literatura}

Afzali, M. H., Sunderland, M., Teesson, M., Carragher, N., Mills, K. i Slade, T. (2017). A network approach to the comorbidity between posttraumatic stress disorder and major depressive disorder: The role of overlapping symptoms. Journal of Affective Disorders, 208, 490-496. https://doi.org/10.1016/j.jad.2016.10.037

Antony, M. M., Bieling, P. J., Cox, B. J., Enns, M. W. i Swinson, R. P. (1998). Psychometric properties of the 42-item and 21-item versions of the Depression Anxiety Stress Scales in clinical groups and a community sample. Psychological Assessment, 10(2), 176-181. https://doi.org/10.1037/1040-3590.10.2.176

Armour, C., Fried, E. I., Deserno, M. K., Tsai, J. i Pietrzak, R. H. (2017). A network analysis of DSM-5 posttraumatic stress disorder symptoms and correlates in U.S. military veterans. Journal of Anxiety Disorders, 45, 49-59. https://doi.org/10.1016/j.janxdis. 2016.11.008

Beard, C., Millner, A. J., Forgeard, M. J. C., Fried, E. I., Hsu, K. J., Treadway, M. T., Leonard, C. V, Kertz, S. J. i Björgvinsson, T. (2016). Network analysis of depression and anxiety symptom relationships in a psychiatric sample. Psychological Medicine, 46(16), 33593369. https://doi.org/10.1017/S0033291716002300

Borsboom, D. (2008). Psychometric perspectives on diagnostic systems. Journal of Clinical Psychology, 64(9), 1089-1108. https://doi.org/10.1002/jclp.20503

Borsboom, D. i Cramer, A. O. J. (2013). Network analysis: An integrative approach to the structure of psychopathology. Annual Review of Clinical Psychology, 9(1), 91-121. https://doi.org/10.1146/annurev-clinpsy-050212-185608

Boschloo, L., van Borkulo, C. D., Borsboom, D. i Schoevers, R. A. (2016). A prospective study on how symptoms in a network predict the onset of depression. Psychotherapy and Psychosomatics, 85(3), 183-184. https://doi.org/10.1159/000442001

Bringmann, L. (2016). Dynamical networks in psychology: More than a pretty picture. [Neobjavljena doktorska disertacija]. KU Leuven. https://doi.org/10.13140/ RG.2.2.28223.10404

Bringmann, L. F., Elmer, T., Epskamp, S., Krause, R. W., Schoch, D., Wichers, M., Wigman, J. T. W. i Snippe, E. (2019). What do centrality measures measure in psychological networks? Journal of Abnormal Psychology. https://doi.org/10.1037/abn0000446

Ciprić, A. i Landripet, I. (2017). Uloga obiteljske socijalizacije i samopoštovanja u odnosu korištenja internetskih društvenih mreža i zadovoljstva tjelesnim izgledom kod adolescentica. Medijska istraživanja, 23(1), 101-125. https://doi.org/10.22572/mi. 23.1.5 
Costantini, G. (2014). Network analysis: A new perspective on personality psychology. [Neobjavljena doktorska disertacija]. University of Milano-Bicocca, Department of Psychology.

Costantini, G., Richetin, J., Preti, E., Casini, E., Epskamp, S. i Perugini, M. (2019). Stability and variability of personality networks. A tutorial on recent developments in network psychometrics. Personality and Individual Differences, 136, 68-78. https://doi.org/10. 1016/j.paid.2017.06.011

Cramer, A. O. J., Kendler, K. S. i Borsboom, D. (2011) Where are the genes? The implications of a network perspective on gene hunting in psychopathology [Komentar rada Johnson et al.]. European Journal of Personality 25, 270-271. https://hdl.handle.net/11245/1. 358220

Cramer, A. O. J., van der Sluis, S., Noordhof, A., Wichers, M., Geschwind, N., Aggen, S. H., Kendler, K. S. i Borsboom, D. (2012). Dimensions of normal personality as networks in search of equilibrium: You can't like parties if you don't like people. European Journal of Personality, 26(4), 414-431. https://doi.org/10.1002/per.1866

Cramer, A. O. J., Waldorp, L. J., Van der Maas, H. L. J. i Borsboom, D. (2010). Comorbidity: A network perspective. Behavioral and Brain Sciences, 33, 137-193. https://doi.org/10. 1017/S0140525X09991567

Csárdi, G. i Nepusz, T. (2006). The igraph software package for complex network research. InterJournal, Complex Systems, 1695(5), 1-9. Preuzeto s https://pdfs.semanticscholar. org/1d27/44b83519657f5f2610698a8ddd177ced4f5c.pdf

Dalege, J., Borsboom, D., van Harreveld, F., van den Berg, H., Conner, M. i van der Maas, H. L. J. (2016). Toward a formalized account of attitudes: The Causal Attitude Network (CAN) model. Psychological Review, 123(1), 2-22. https://doi.org/10.1037/a0039802

Dalege, J., Borsboom, D., van Harreveld, F. i van der Maas, H. L. J. (2017). Network analysis on attitudes. Social Psychological and Personality Science, 8(5), 528-537. https://doi.org/10.1177/1948550617709827

Dalege, J., Borsboom, D., van Harreveld, F. i van der Maas, H. L. J. (2019). A network perspective on attitude strength: Testing the connectivity hypothesis. Social Psychological and Personality Science, 10(6), 746-756. https://doi.org/10.1177/ 1948550618781062

Dalege, J., Borsboom, D., van Harreveld, F., Waldorp, L. J. i van der Maas, H. L. J. (2017). Network structure explains the impact of attitudes on voting decisions. Scientific Reports, 7(1), 4909. https://doi.org/10.1038/s41598-017-05048-y

David, S. J., Marshall, A. J., Evanovich, E. K. i Mumma, G. H. (2018). Intraindividual dynamic network analysis - Implications for clinical assessment. Journal of Psychopathology and Behavioral Assessment, 40(2), 235-248. https://doi.org/10.1007/ s10862-017-9632-8

Edwards, J. R. i Bagozzi, R. P. (2000). On the nature and direction of relationships between constructs and measures. Psychological Methods, 5(2), 155-174. https://doi.org/10. 1037/1082-989X.5.2.155 
Epskamp, S. (2017). Network psychometrics. [Nebjavljena doktorska disertacija]. University of Amsterdam.

Epskamp, S. (2019). Package "bootnet" - Bootstrap methods for various network estimation routines. Preuzeto s https://cran.r-project.org/web/packages/bootnet/bootnet.pdf

Epskamp, S., Borsboom, D. i Fried, E. I. (2018). Estimating psychological networks and their accuracy: A tutorial paper. Behavior Research Methods, 50(1), 195-212. https://doi.org/ 10.3758/s13428-017-0862-1

Epskamp, S., Cramer, A. O. J., Waldorp, L. J., Schmittmann, V. D. i Borsboom, D. (2012). qgraph: Network visualizations of relationships in psychometric data. Journal of Statistical Software, 48(4), 1-18. https://doi.org/10.18637/jss.v048.i04

Epskamp, S. i Fried, E. I. (2018). A tutorial on regularized partial correlation networks. Psychological Methods, 23(4), 617-634. https://doi.org/10.1037/met0000167

Epskamp, S., Kruis, J. i Marsman, M. (2017). Estimating psychopathological networks: Be careful what you wish for. PLOS ONE, 12(6), 1-13. https://doi.org/10.1371/journal. pone. 0179891

Epskamp, S., Maris, G., Waldorp, L. J. i Borsboom, D. (2017). Network psychometrics. U: P. Irwing, T. Booth i D. J. Hughes (Ur.), The Wiley handbook of psychometric testing: A multidisciplinary reference on survey, scale and test development (Vol 2, str. 953986). Wiley. https://doi.org/10.1002/9781118489772.ch30

Epskamp, S., Waldorp, L. J., Mõttus, R. i Borsboom, D. (2018). The Gaussian Graphical Model in Cross-Sectional and Time-Series Data. Multivariate Behavioral Research, 53(4), 453-480. https://doi.org/10.1080/00273171.2018.1454823

Forbush, K. T., Siew, C. S. Q. i Vitevitch, M. S. (2016). Application of network analysis to identify interactive systems of eating disorder psychopathology. Psychological Medicine, 46(12), 2667-2677. https://doi.org/10.1017/S003329171600012X

Forrest, L. N., Jones, P. J., Ortiz, S. N. i Smith, A. R. (2018). Core psychopathology in Anorexia nervosa and Bulimia nervosa: A network analysis. International Journal of Eating Disorders, 51(7), 668-679. https://doi.org/10.1002/eat.22871

Fried, E. I. i Cramer, A. O. J. (2017). Moving forward: Challenges and directions for psychopathological network theory and methodology. Perspectives on Psychological Science, 12(6), 999-1020. https://doi.org/10.1177/1745691617705892

Fried, E. I., Eidhof, M. B., Palic, S., Costantini, G., Huisman-van Dijk, H. M., Bockting, C. L. H., Engelhard, I., Armour, C., Nielsen, A. B. S. i Karstoft, K.-I. (2018). Replicability and generalizability of posttraumatic stress disorder (PTSD) networks: A cross-cultural multisite study of PTSD symptoms in four trauma patient samples. Clinical Psychological Science, 6(3), 335-351. https://doi.org/10.1177/2167702617745092

Fried, E. I., Epskamp, S., Nesse, R. M., Tuerlinckx, F. i Borsboom, D. (2016). What are "good" depression symptoms? Comparing the centrality of DSM and non-DSM symptoms of depression in a network analysis. Journal of Affective Disorders, 189, 314 320. https://doi.org/10.1016/j.jad.2015.09.005 
Fruchterman, T. M. J. i Reingold, E. M. (1991). Graph drawing by force-directed placement. Software - Practice and Experience, 21(11), 1129-1164.

Heeren, A. i McNally, R. J. (2016). An integrative network approach to social anxiety disorder: The complex dynamic interplay among attentional bias for threat, attentional control, and symptoms. Journal of Anxiety Disorders, 42, 95-104. https://doi.org/10. 1016/j.janxdis.2016.06.009

Henry, J. D. i Crawford, J. R. (2005). The short-form version of the Depression Anxiety Stress Scales (DASS-21): Construct validity and normative data in a large non-clinical sample. British Journal of Clinical Psychology, 44(2), 227-239. https://doi.org/10.1348/ $014466505 \times 29657$

Jones, P. J., Ma, R. i McNally, R. J. (2019). Bridge centrality: A network approach to understanding comorbidity. Multivariate Behavioral Research, 1-15. https://doi.org/10. 1080/00273171.2019.1614898

Jones, P. J., Mair, P., Riemann, B. C., Mugno, B. L. i McNally, R. J. (2018). A network perspective on comorbid depression in adolescents with obsessive-compulsive disorder. Journal of Anxiety Disorders, 53, 1-8. https://doi.org/10.1016/j.janxdis.2017.09.008

Lindberg, S. M., Hyde, J. S. i McKinley, N. M. (2006). A measure of objectified body consciousness for preadolescent and adolescent youth. Psychology of Women Quarterly, 30(1), 65-76. https://doi.org/10.1111/j.1471-6402.2006.00263.x

Lovibond, P. F. i Lovibond, S. H. (1995). The structure of negative emotional states: Comparison of the Depression Anxiety Stress Scales (DASS) with the Beck Depression and Anxiety Inventories. Behaviour Research and Therapy, 33(3), 335-343. https://doi.org/10.1016/0005-7967(94)00075-U

McNally, R. J., Mair, P., Mugno, B. L. i Riemann, B. C. (2017). Co-morbid obsessivecompulsive disorder and depression: A Bayesian network approach. Psychological Medicine, 47(7), 1204-1214. https://doi.org/10.1017/S0033291716003287

McNally, R. J., Robinaugh, D. J., Wu, G. W. Y., Wang, L., Deserno, M. K. i Borsboom, D. (2015). Mental disorders as causal systems: A network approach to posttraumatic stress disorder. Clinical Psychological Science, 3(6), 836-849. https://doi.org/10.1177/ 2167702614553230

Mendelson, B. K., Mendelson, M. J. i White, D. R. (2001). Body-esteem scale for adolescents and adults. Journal of Personality Assessment, 76(1), 90-106. https://doi.org/10.1207/ S15327752JPA7601_6

Milas, G., Wright, P. i Štulhofer, A. (2020). Longitudinal assessment of the association between pornography use and sexual satisfaction in adolescence. Journal of Sex Research, 57(1), 16-28. https://doi.org/10.1080/00224499.2019.1607817

Molenaar, P. C. M. (2010). Latent variable models are network models. [Komentar na rad "Comorbidity: A network perspective", autora Cramer, A. O. J., Waldorp L. J., van der Maas, H. L. J., Borsboom D.]. Behavioral and Brain Sciences, 33, 166. https://doi.org/10.1017/S0140525X10000798 
Nuijten, M. B., Deserno, M. K., Cramer, A. O. J. i Borsboom, D. (2016). Mental disorders as complex networks: An introduction and overview of a network approach to psychopathology. Clinical Neuropsychiatry, 13(4/5), 68-76.

Olatunji, B. O., Levinson, C. i Calebs, B. (2018). A network analysis of eating disorder symptoms and characteristics in an inpatient sample. Psychiatry Research, 262, 270 281. https://doi.org/10.1016/j.psychres.2018.02.027

Opsahl, T., Agneessens, F. i Skvoretz, J. (2010). Node centrality in weighted networks: Generalizing degree and shortest paths. Social Networks, 32(3), 245-251. https://doi.org/10.1016/j.socnet.2010.03.006

Preszler, J., Marcus, D. K., Edens, J. F. i McDermott, B. E. (2018). Network analysis of psychopathy in forensic patients. Journal of Abnormal Psychology, 127(2), 171-182. https://doi.org/10.1037/abn0000325

Richetin, J., Preti, E., Costantini, G. i De Panfilis, C. (2017). The centrality of affective instability and identity in Borderline Personality Disorder: Evidence from network analysis, PLOS ONE, 12(10), e0186695. https://doi.org/10.1371/journal.pone.0186695

Robinaugh, D. J., Millner, A. J. i McNally, R. J. (2016). Identifying highly influential nodes in the complicated grief network. Journal of Abnormal Psychology, 125(6), 747-757. https://doi.org/10.1037/abn0000181

Rodgers, R. F., DuBois, R., Frumkin, M. R. i Robinaugh, D. J. (2018). A network approach to eating disorder symptomatology: Do desire for thinness and fear of gaining weight play unique roles in the network? Body Image, 27, 1-9. https://doi.org/10.1016/ J.BODYIM.2018.07.004

Santos, H. P., Kossakowski, J. J., Schwartz, T. A., Beeber, L. i Fried, E. I. (2018). Longitudinal network structure of depression symptoms and self-efficacy in lowincome mothers. PLOS ONE, 13(1), e0191675. https://doi.org/10.1371/journal.pone. 0191675

Schmittmann, V. D., Cramer, A. O. J., Waldorp, L. J., Epskamp, S., Kievit, R. A. i Borsboom, D. (2013). Deconstructing the construct: A network perspective on psychological phenomena. New Ideas in Psychology, 31, 43-53. https://doi.org/10.1016/j. newideapsych.2011.02.007

Southward, M. W. i Cheavens, J. S. (2018). Identifying core deficits in a dimensional model of Borderline Personality Disorder features: A network analysis. Clinical Psychological Science, 6(5), 685-703. https://doi.org/10.1177/2167702618769560

Thompson, J. K., Van Den Berg, P., Roehrig, M., Guarda, A. S. i Heinberg, L. J. (2004). The Sociocultural Attitudes Towards Appearance Scale-3 (SATAQ-3): Development and validation. International Journal of Eating Disorders, 35(3), 293-304. https://doi.org/ 10.1002/eat.10257

Tsang, S. i Salekin, R. T. (2018). The network of psychopathic personality traits: A network analysis of four self-report measures of psychopathy. Personality Disorders: Theory, Research, and Treatment, 10(3), 246-256. https://doi.org/10.1037/per0000319

Van Borkulo, C. (2019). Package "NetworkComparisonTest" - Statistical comparison of two networks based on three invariance measures version. https://doi.org/10.13140/ RG.2.2.29455.38569 
Van Borkulo, C., Waldorp, L. J., Boschloo, L., Kossakowski, J., Tio, P., Schoevers, R. A. i Borsboom, D. (2016). Comparing network structures on three aspects: A permutation test. Preprint. https://doi.org/10.13140/RG.2.2.29455.38569

Verschuere, B., van Ghesel Grothe, S., Waldorp, L., Watts, A. L., Lilienfeld, S. O., Edens, J. F., Skeem, J. L. i Noordhof, A. (2018). What features of psychopathy might be central? A network analysis of the Psychopathy Checklist-Revised (PCL-R) in three large samples. Journal of Abnormal Psychology, 127(1), 51-65. https://doi.org/10.1037/ abn0000315

Waldorp, L. J., Blanken, T. F., Boschloo, L., Borsboom, D., Schoevers, R. A., Epskamp, S. i van Borkulo, C. D. (2014). A new method for constructing networks from binary data. Scientific Reports, 4(1), 1-10. https://doi.org/10.1038/srep05918

Wang, S. B., Jones, P. J., Dreier, M., Elliott, H. i Grilo, C. M. (2019). Core psychopathology of treatment-seeking patients with binge-eating disorder: A network analysis investigation. Psychological Medicine, 49(11), 1923-1928. https://doi.org/10.1017/ S0033291718002702

Werner, M. A. (2018). Technical Note: The ComDet Package - Iterated Community Detection for the Analysis of Community Membership, its Stability and the Detection of Fuzzy Community Boundaries. OSP Preprints. http://doi.org/10.31219/osf.io/bwsq7

\title{
Application of the Network Analysis in Psychological Research
}

\begin{abstract}
The network approach represents a novel paradigm for exploring relations between psychological constructs and observable variables. According to this approach, variables form an autonomous dynamical system; the psychological construct is therefore not viewed as their common cause, but a result of their complex interactions. From an analytical point of view, this approach is based on network analysis - a set of procedures which models variables as nodes connected by a set of edges. This paper presents an overview of network analytical procedures. In other words, it offers a brief explanation of the methods, as well as their practical application in two separate datasets. The first dataset represents data on DASS-21 $(N=1016)$ and it serves to demonstrate network estimation, centrality measures calculation, community detection and network stability analyses. According to the results, the highest centrality was obtained for the depression item I felt that I had nothing to look forward to, anxiety item I felt I was close to panic, and stress item I felt that 1 was using a lot of nervous energy. As expected, nodes were grouped into three clusters, namely Depression, Anxiety and Stress. Stability analyses demonstrated limited stability of edge strength, while the stability of node centrality depended on the measure used. In the second dataset, which represents data on adolescents' attitudes towards one's body appearance, the Network Comparison Test was demonstrated by comparing male $(n=524)$ and female $(n=763)$ networks. Results showed that the two networks do not differ substantially.
\end{abstract}

Keywords: network approach, network analysis, nodes, edges, centrality measures

Primljeno: 15. 2. 2020. 


\section{R-skripta - mrežna analiza}

library(bootnet) \#network stability library(qgraph) \#network analysis library(igraph) \#network analysis library(foreign) \#read SPSS data library(NetworkComparisonTest) \#network comparison library(openxlsx) \#data export

\section{\#STUDY1}

dataDASS <- read.spss("DASS.sav", to.data.frame $=$ TRUE)

corrDASS <- cor_auto(dataDASS)

graphDASS <- estimateNetwork(dataDASS, default = "EBICglasso", labels $=$ colnames $($ dataDASS $)$,

\#Centrality plot tuning $=0.5$ )

centralityPlot(graphDASS, include $=$ "all")

\#Edge weights table export

write.xlsx (graphDASS\$graph, file = "Edges.xlsx")

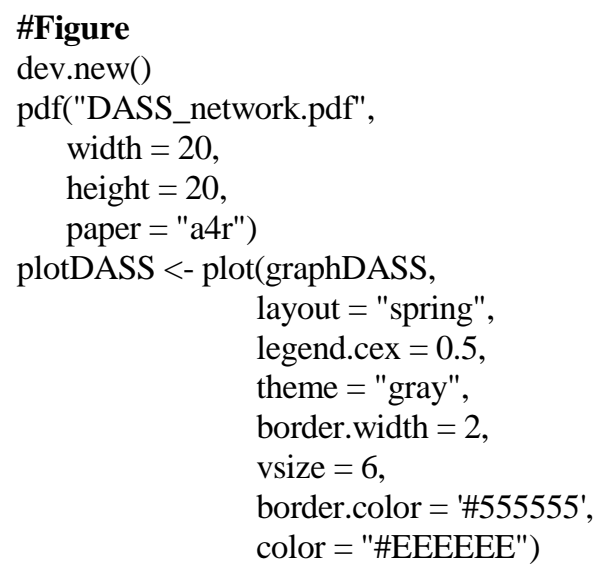


\#Community detection (spinglass) ${ }^{2}$

qgraphDASS <- qgraph(corrDASS,

$$
\begin{aligned}
& \text { sampleSize = nrow(dataDASS }), \\
& \text { graph }=\text { "glasso", } \\
& \text { layout = "spring", } \\
& \text { tuning }=0.5 \text { ) } \\
& \text { ph(qgraphDASS, } \\
& \text { attributes = TRUE) }
\end{aligned}
$$

igraphDASS <- as.igraph(qgraphDASS,

spinglassDASS <- spinglass.community(igraphDASS)

\section{\#Edge stability}

edgeStabilityDASS <- bootnet(graphDASS,

$$
\begin{aligned}
& \text { nBoots }=5000, \\
& \text { nCores }=3 \text { ) }
\end{aligned}
$$

plot(edgeStabilityDASS,

order = "sample",

labels $=$ TRUE,

$\operatorname{mar}=\mathrm{c}(1,1,1,1)$,

sampleColor = '\#555555')

\section{\#Centrality stability}

centralityStabilityDASS <- bootnet $($ data $=$ graphDASS,

$$
\begin{aligned}
& \text { type }=\text { "case", } \\
& \text { nBoots }=5000, \\
& \text { nCores }=3, \\
& \text { verbose = TRUE, } \\
& \text { statistics }=\text { c("strength", }
\end{aligned}
$$

"closeness", "betweenness",

"expectedInfluence"))

plot(centralityStabilityDASS,

statistics = c("strength", "closeness", "betweenness",

"expectedInfluence"),

plot $=$ "area")

\footnotetext{
${ }^{2}$ Iz koda je izostavljen algoritam koji iterativno provodi analizu kroz 1000 iteracija kako bi se dobilo najstabilnije rješenje. Algoritam je razvila autorica rada i nije dio standardnih paketa, a na upit se može dobiti od autorice.
} 


\section{\#STUDY2}

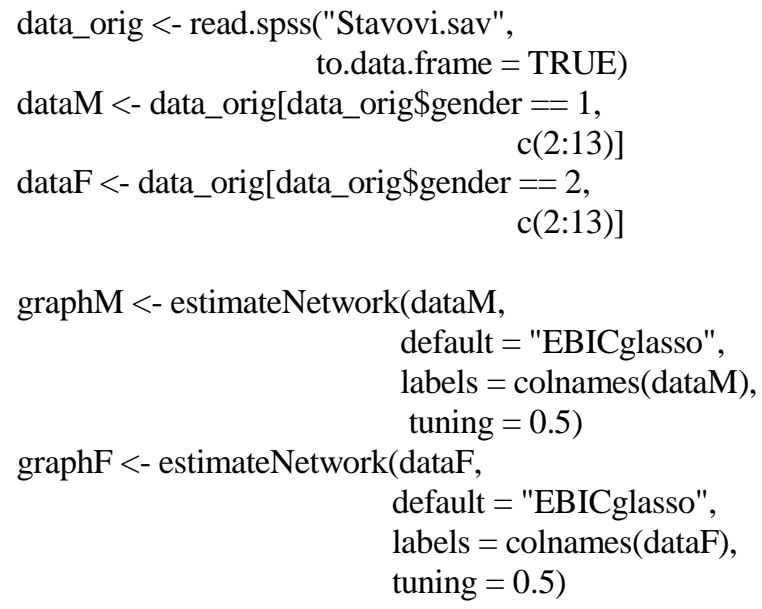

\section{\#Figure}

dev.new()

pdf("Stavovi.pdf",

width $=20$,

height $=20$,

paper $=$ "a4r")

$\operatorname{par}(\operatorname{mfrow}=\mathrm{c}(1,2))$

averageLayout <- averageLayout(graphM, graphF)

plotM <- plot(graphM,

layout $=$ averageLayout,

legend.cex $=0.5$,

title $=$ "Muškarci",

title.cex $=1.5$,

theme $=$ "gray",

border.width $=2$,

vsize $=6$,

border.color $=$ '\#555555',

color = "\#EEEEEE")

plotF <- plot(graphF,

layout $=$ averageLayout,

legend.cex $=0.5$,

title $=$ "Žene",

title.cex $=1.5$,

theme $=$ "gray",

border.width $=2$,

vsize $=6$,

border.color = '\#555555',

dev.off()

color = "\#EEEEEE") 
\#Network Comparison Test

comparison <- NCT(graphM,

graphF,

it $=1000$,

test.edges $=$ TRUE,

edges = "all",

comparison

p.adjust.methods = "holm") 